\title{
TECHNOLOGY TRANSFER IN THE GENETIC IMPROVEMENT PROGRAM OF SUGAR CANE FROM UFPR
}

\author{
DE-CARLI, Eduardo ${ }^{1}$; SEGATTO, Andréa Paula ${ }^{2}$ and SINGH, Ananda Silva ${ }^{3}$ \\ Federal University of Paraná 1, eduardodecarli@ufpr.br, https://orcid.org/0000-0001-5853-9488 \\ Federal University of Paraná 2, aps@ufpr.br, https://orcid.org/0000-0002-8903-9256 \\ Federal University of Uberlandia 3, a.singh@uol.com.br, https://orcid.org/0000-0003-4919-5649
}

\begin{abstract}
This study aims at promoting an analysis of the process of technology transfer undertaken by Federal University of Paraná (UFPR), by means of the activities developed in the Genetic Improvement Program of Sugar Cane for the development of new technologies, new varieties of sugar cane. To do so, a single case study performed at the UFPR is held, aiming at identifying the main aspects that involve this process from the point of view of an institution. It was possible to notice that it creates a stimulus to the development of knowledge about a particular variety of the sugar cane plant by means of the interaction between the ten universities and also with its partners, in order to develop a variety more genetically developed that allows, for example, increased productivity. The technology transfer in the course of the process allows the development of several new varieties of sugar cane, in addition to providing expertise to members of the project. It is of fundamental importance for the activities and varieties to be carried out in a better way every time.
\end{abstract}

KEY WORDS: Technology Transfer; Interorganizational network; Case Study.

\section{INTRODUCTION}

The key factor for a society to progress and for an organization to innovate technologically lies in the development of knowledge and the interactions that occur in the course of this journey. Therefore, it leads to progress when knowledge and learning as the basis for innovation are established (Lundvall, 2007), because the ability to change the 'natural' environment lies in developing innovations from knowledge (Leydesdorff, 2018), which enables maintaining and reaching new markets (Carayannis, Samara, \& Bakouros, 2015).

There is the development of knowledge, a cooperation that will lead to the creation of innovations. It is in this perspective that the technology transfer (TT) lies, i.e., this type of transfer involves aspects such as the integration of ideas with which new techniques for the expansion of knowledge are developed (Bozeman, 2000; Pagani, Zammar, Kovaleski, \& Resende, 2016) contributing to improvements in various areas.

The TT matches the absorption, distribution or creation of new technologies (Bozeman, Rimes, \& Youtie, 2015; Mazurkiewicz \& Poteralska, 2015), factors that boost the economic and social development (Mazurkiewicz \& Poteralska, 2015), that stimulate innovations and improvements in the progress of activities and even in the empowerment of people, which can evolve in its competencies for the implementation of improvements in the technical tasks that are performed.

TT involves personnel, communication, information, as well as the exchange of resources and adequate infrastructure, since in its activities there are knowledge, risks and benefits that are shared between its actors (Kaushik, Kumar, Luthra, \& Haleem, 2014; Rogers et al., 2001) for the range of benefits. In the interorganizational cooperation resources and complementary skills are shared aiming at knowledge development (De-Carli, Segatto, \& Alves, 2016), as well as in the technological development in which there is a TT.
There is a learning process of knowledge through which the technology is developed, in which there are three types of content to be transferred: (i) goods and equipment, (ii) skills and know-how for the use and maintenance of the equipment, and (iii) knowledge to manage the technological changes (Pueyo, Garcia, Mendiluce, \& Morales, 2011).

According to Elmuti, Abebe and Nicolosi (2005), Cecere et al. (2014), Rajalo and Vadi (2017), Huang and Chen (2017), in the academic researches lies one of the keys to opportunities for technology transfer. Sengupta and Ray (2017) emphasize that the past performance of a university along the pillar of research strengthens the pillar of knowledge transfer over time, by means of marketing channels and academic engagement. This is so due to the fact that universities have a central role, mainly due to its unique ability to produce scientific knowledge of border (De Silva \& Rossi, 2018; Etzkowitz, 2017).

It is in this perspective that this study is held, as it discusses the process of TT by universities that develop varieties of sugar cane and that comprise the "Genetic Improvement Program of Sugar Cane" (PMGCA), comprising a network of ten Brazilian federal universities that constitute the Inter-university network for the development of the sugar cane sector (RIDESA).

As it is up to these universities to develop and share research activities "among all universities, stimulating the exchange of information, knowledge and results. This greatly increases the capacity and the national coverage of the results of the research and innovation" (Daros, Zambon, \& Oliveira, 2016, p. 43), because there is a stimulus to technological development, via competition in the development of new technologies for these institutions, each of which is taking advantage of the resources it has and how to put them into practice in this process.

\section{TECHNOLOGY TRANSFER (TT)}

The technology transfer consists in an intentional process interaction between two or more entities, with the objective of increasing the knowledge transferred/technology (Battistella, Toni, \& Pillon, 2016) and that stimulates innovation (Rajalo \& 
Vadi, 2017). "Inter-organizational knowledge transfer involves at least two organizations, and we therefore need to understand the interactive dynamics between these organizations" (Easterby-Smith, Lyles, \& Tsang, 2008, p. 679). The "knowledge is a primordial factor in TT; it is the main resource transferred between people" (Pagani et al., 2016, p. 23) and it is from such knowledge which, in TT, exchange of information, resources, technical knowledge, experience (Bozeman, 2000; Bozeman et al., 2015).

Transfer of technology is the basis for organizations to elevate the production of its innovations (Carayannis et al., 2015), to develop knowledge by means of which the activities are enhanced. This occurs in view of the fact that the knowledge transfer is also linked to aspects by means of which "an event through which one organization learns from the experience of another" (Easterby-Smith et al., 2008, p. 677). In this sense, it develops the know-how and if transmits this between the parties that relate, for example, in relation to cooperation between universities (De Silva \& Rossi, 2018), cooperation between universities and enterprises (Noveli \& Segatto, 2012), to ensure that the 'technology leave a place and will take place in another (Carayannis et al., 2015).

The TT consists in a process between different actors, whose interaction provides greater abilities by means of which explore the technology in the most different possibilities (Petroni, Verbano, Bigliardi, \& Galati, 2013), in addition which allows the acquisition of foreign technology, this aspect that prevents the loss of time and resources already available (Barbieri, 1990).

With the integration of ideas for the expansion of knowledge (Bozeman, 2000; Pagani et al., 2016), in the processes of TT involves elements such as personnel, communication, information, resources and structure, due to the involvement of knowledge, risks and benefits shared by parties that interact (Kaushik et al., 2014; Rogers et al., 2001), in order to move the technology from one side to the other, i.e., so that the technology can be learned and used in accordance with some purpose (Bozeman, 2000; Carayannis et al., 2015) and for some improvement.

Thus, it is noteworthy that actors use TT to acquire technology and knowledge that are systematized and states in productive processes and for the development of innovations, which tends to generate competitive advantage and ensure economic growth (Pagani et al., 2016). In this sense, the "TT may be referred to as a process/'series of activities' in which knowledge, costs, risks, and benefits are shared among various economic entities and individual/group of people in modern human Society" (Kaushik et al., 2014, p. 134).

In the TT there is absorption, distribution or creation of new technologies (Bozeman et al., 2015; Mazurkiewicz \& Poteralska, 2015) for innovations and improvements in the progress of activities and so that it is possible to download related content, including the skills and know-how for the use and maintenance of the equipment, as well as managing the technological changes (Pueyo et al., 2011). With this, the "implementation of TT will help in reducing costs as well as increasing firms' competitiveness" (Kaushik et al., 2014, p. 154).

It is worth noting that the transfer of knowledge is a complex phenomenon and, in practice, the successful transfer is often not easy to reach, as it can be impediments and or barriers that prevent this from happening. "Transferring knowledge between organizations brings more complexity because of the multifaceted nature of the boundaries, cultures, and processes involved" (Easterby-Smith et al., 2008, p. 677). For example, Henderson, Jaffe and Trajtenberg (1998) affirm that it is necessary to establish a trajectory of development, because the university inventions are a secondary product of research and have them in the focus of the processes becomes something increasingly important institutions.

When considered the TT in universities, Caldera and Debande (2010, p. 1172) affirm that "university internal technology transfer policies and the nature and type of technology transfer intermediaries are important factors influencing the performance of universities". In the face of such aspects, believes that the process of TT occurs so that you can 'walk' on technological development, and that through such a transfer is that it is possible to develop greater abilities by means of which explore the technology with a purpose.

\section{METHODOLOGICAL PROCEDURES}

This research adopts a qualitative approach, since it worked with interpretations of social realities (Bauer \& Gaskell, 2002) in which it is possible to conduct in-depth studies by means of which it is possible to represent opinions of participants (Yin, 2016) as in the case outlined, i.e., of the participant regarding the process of technology transfer in the project analyzed.

This type of approach seeks to examine a phenomenon from the perspective of the authors, based on the interpretation of the case study (Merriam, 2009). The case in question is the PMGCA and its selection for the study occurs because it isthe most fruitful performed, up to the moment, by UFPR, administered by the Federal University of Paraná Foundation (FUNPAR) in partnership with other institutions, since there is technology transfer, it already generates royalties for the university and it is the most splendid project or that sells all the expensive technology from the university and by means of which there are already more than 25 years of research.

To do so, a descriptive study is held, in order to identify and obtain information that highlights the study itself (Collis \& Hussey, 2005) and characteristics that determine it. Such a description comes from the design of the case study, since it seeks to analyze a particular phenomenon in depth, considering aspects of 'how' and 'why' this phenomenon occurs (Yin, 2015).

The data collection was guided on several sources of evidence, so that it is possible to deepen the understanding (Yin, 2015) and triangular data, helping ensure the internal validity and reliability of the study. Thus, three in-depth interviews with the researcher, former coordinator of the project [E1] were held, and the first was conducted with the aim of (i) better knowing the project, as well as identify its participants; the second interview aimed at (ii) seeking more details about how the project is developed within the UFPR and how relationships are developed with other universities, and, finally, a third interview was conducted for the purpose of (iii) checking the veracity of the information, possible failures of understanding and complementing the information obtained previously. In addition, four interviews were conducted with the then vicecoordinator of the project [E2], following the same prerogatives of the previous interview.

These interviews generated $3 \mathrm{~h} 25 \mathrm{~m}$ of recorded conversations in the period of September 2017 to October 2018, totaling 59 pages transcribed, besides the possibility of monitoring of two face-toface meetings, that took place in August 2018, made with all members of the network. 
For data analysis, the content analysis technique was used, with the objective to analyze the information obtained in the interviews, elaborating categories of analysis based on the literature, which are related to the process of TT, characterized by (i) goods and equipment, (ii) skills and know-how for the use and maintenance of the equipment, and (iii) knowledge to manage the technological changes (Pueyo et al., 2011).

After the data were classified, inferences were carried forward to the collected data and the theory of the theme dealt with here (as it develops the process of technology transfer in the case studied). In relation to the rigor of the research, it is considered aspects of validity, with information about reality, and reliability, with the goal of promoting the replication of the study and, consequently, to be able to reach the saturation of information (Merriam, 2009).

\section{CHARACTERIZATION OF THE PROJECT AND OF THE CASE}

The origin of the sugar cane project, case in question stems from the Sugar and Alcohol Institute (IAA), "a municipality of the Brazilian federal administration", created in 1933, as a component of the then Ministry of Industry and Trade, which aimed to regulate the production of sugar in the country and the promotion of the production of alcohol, being that their objectives were to guide, encourage and achieve control of the production of sugar and alcohol and their raw materials throughout the national territory" (Daros et al., 2016, p. 25).

Its by means of 'planalsucar' created in 1971, which starts all searches with the sugar cane cultivation until 1989, year in which it is terminated by political issues. With the extinction of this institute, took the cane research of some Brazilian federal public universities: the Federal Rural University of Pernambuco (UFRPE), the Federal University of Alagoas (UFAL), the Federal Rural University of Rio de Janeiro (UFRRJ), the Federal University of São Carlos (UFSCAR) and the Federal University of Viçosa (UFV) are those which begin this process, each with some expertise and/or structure in the area.

Also, there were several regional stations, which were in Mato Grosso, Mato Grosso do Sul, Goiás, Maranhão and also in Paraná, units of the Brazilian federation. In all there were 33 regional stations to do research with sugar cane. It is at this moment, in 1992, that the Federal University of Paraná (UFPR) begins to take part in the program and to develop research with sugar cane.

In this sense, because it is a study whose objective is to explain a definition of a social group, in which individuals participating in the study must have similarities and differences, the proposal if selected for study correspond to the PMGCA, a program developed by federal universities.

These authors affirm that the program was born in support of "areas traditionally producers of sugar cane" to meet the demands of alcohol. With this, "were incorporated new agricultural areas in the production process, verifying if the influx of new entrepreneurs and the rapid expansion of sugarcane for regions where, until then, this culture was virtually non-existent".

It is a project developed by ten Brazilian federal public universities, which must develop and share research activities "among all universities, stimulating the exchange of information, knowledge and results. This greatly increases the capacity and the national coverage of the results of the research and innovation" (Daros et al., 2016, p. 43), by means of partnership agreements.

The ten Brazilian public federal universities that integrate the RIDESA, created in 1990, are: Federal University of Alagoas (UFAL), Federal University of Goiás (UFG), Federal University of Mato Grosso (UFMT), Federal University of Paraná (UFPR), Federal University of Piauí (UFPI), Federal Rural University of Pernambuco (UFRPE), Federal Rural University of Rio de Janeiro (UFRRJ), Federal University of São Carlos (UFSCar), Federal University of Sergipe (UFS), Federal University of Viçosa (UFV) (Ridesa, 2018).

One of the partner universities is the UFPR, which has headquarters in Curitiba - PR and currently has 25 factories and associations as contracted units (Ridesa, 2018). The university initiates the participation in the ridesa in 1992, from the integration of two experimental stations, located in Paranavaí and Bandeirantes, both in the state of Paraná and which until then were under the supervision of ufscar. With the transmission of "the entire structure and technical acquis and staff [...] began talks of how would occur the conduct of the program of sugar cane" (Daros et al., 2016, p. 50).

The UFPR participation occurred after the UFRPE and UFAL, both of which had an own station for cultivation of sugarcane, the UFRRJ, UFSCAR and the UFV, the first five universities to integrate the old IAA and planalsucar. It is noteworthy that the effective participation of the UFPR was (and is) tied to its foundation, i.e., the FUNPAR, through which the processes of cooperation began to be managed and by means of which it was possible to give agility to activities. 


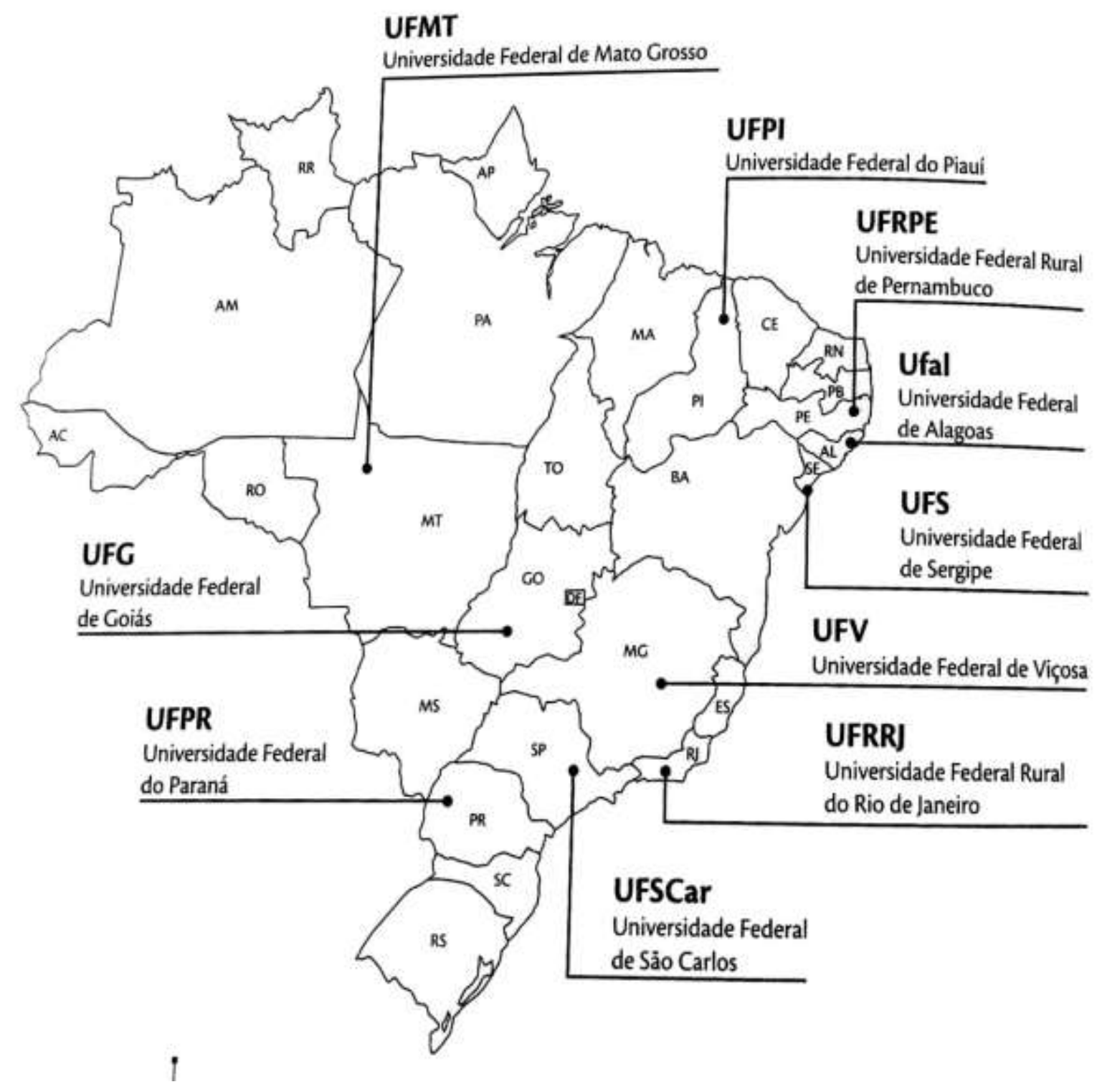

Figure 1 - Ten Brazilian public federal universities

Source: Daros, Zambon e Oliveira (2016, p. 42)

\section{DATA PRESENTATION}

Begin the challenges since, according to E1, "How do you work with 10 universities? 10 universities, all of them are working, doing what we do that is genetic improvement". The first step in the development of the UFPR consisted in developing a variety of sugar cane of the UFPR: "Although we take 18 years [between 1992 and 2010, in which year was the first great material of the UFPR - our emphasis], which was the work of the UFPR during these 18 years? First, try to obtain a variety of UFPR [...] second, catch the other varieties... test them and put them to them for planting".

So that it would be possible to acquire these varieties, the free and available by means of the interconnection between the universities that are part of the RIDESA, in which the initial objective was to exchange materials, test them, so that it was possible to identify the best and, consequently, contribute to the development of a variety itself. Then E1 points out that "this network the materials have been tested and everyone was the best. Until we establish our. So this was the great merit, too". To receive the material showed the possibility of use of that best suited to the local reality, being that the experience developed with the tests would be replaced/transferred to the partner.

It is noteworthy that the evolution of research demanded of interconnection capacity with partners, something that provided a leap in quality and development of technological improvements from the TT. "Instead of five hundred thousand [seedlings per 3 thousand $\mathrm{m} 2$ ], we went to 10 million". There was an evolving technology, which modifies and expands with the development of the project and with the integration of technical procedures. This is coupled, as says E2, the partnership established in the field for the development of collaborative innovation, because "each plant has an area that is planted with varieties of network, the RIDESA [...], our project partners with the mills also because they assemble experiments within the mills, the materials are being developed to try to find the best varieties". With the integration and technology transfer with the plants, it became possible to evolve in search of sugar cane.

Transfer technology enables sides that interact to build media and/or mechanisms by means of which will develop skills and capacities with which might develop their activities in such a way better every time, either by technical training, either by 
expansion of know-how, by the development of knowledge and expertise with which to improve practice, as has already been highlighted. As E1, "We have 10 breeding programs, the best breeding program today, within the Federal University of Paraná. This is what we are known. This is what we become known. The University, not us, indirectly, hence my comments: - 'Ah, is the [Professor $\mathrm{X}],[\mathrm{Y}]$, Teacher is another...', there is no University, look we are a team, personnel, no one does anything alone and I am over 18 face in the field to help me". This interaction and exchange of information, experiences and knowledge both among researchers, as between the other members that participate in the cultivation of sugar cane is that it develops the TT.

To do this at the university, it was possible to develop numerous innovations from sugar cane that could develop technologies able to meet throughout Brazil, according to E1 says: "The University has the competence to stay with the responsibility of search and retrieval of varieties of sugarcane in Brazil". Collaborative Knowledge were created from cooperation between university and company and university-university (via Network) who were able to stimulate and develop this type of improvements.

And not only that, processes of TT became increasingly common, because with this, showed the possibility of developing improvements in plant varieties of sugar cane for which could be planted by the mills of partner universities. Fact is that the process of TT carried out under the coordination of the UFPR enabled, for example in the case of Paraná State, were to be developed mechanisms for the capacitation of professionals. As stated by the E1 interviewee: "I use the institutions, can you use, we use a lot to Estadual University of Maringá [UEM] also [...] in the research that we did together [...] the surveys that we conduct, the staff of the UEM entered. Lease areas to their masters, doctorate in stations, on units"

To assign areas for master's and doctoral degrees, allowed for an exchange of information, the interrelationship between the institutions for the development of knowledge sets, in which one party eventually contribute with the other in the formation of human resources even more empowered, with the exchange of experiences and know-how. The interconnector which occurred in the exchange with researchers from different areas and skills, who brought knowledge of their practices in different regions, it became possible to TT.

Another way to such emphasis is occurs in the transfer of technology outlined in the course of the process with the productive sector. E1 says: "what the university did so well? Well, we are teaching. Great! So what we have to offer? We offer teaching. It gives you a symposium, gives you course, for everything that is part [...] and our 'grand finale' was when we discovered, the agronomic residence in the Federal Rural do Rio de Janeiro. And then we put 30 within factory and 110 new agronomists". This exchange of experiences led to greater knowledge and, consequently, has opened opportunities for the training of personnel for a better development of technologies.

It is noteworthy that the agronomic residence highlighted here consists in the training of professionals recently graduated in agronomy. This residence consists in "a program aimed the Agronomists newly formed, which aims to promote the improvement of knowledge, skills and attitudes essential to the exercise of Agronomy through intensive training in service, under supervision, in addition to developing a sense of ethical responsibility in the exercise of their professional activities" (UFRRJ, 2018).
This occurred in view that many professionals formed by these universities had few opportunities to market due to the lack of experience with the cultivation of sugar cane cultivation. To empower them, was created the program of residence for a period of one year. To be allowed access to the agronomists from any part of Brazil, facilitated the access to distinct knowledge.

Allied to this, another point of development of technologies is the expertise created, for example, by means of studies undertaken within the UFPR: - "We have modified the breeding program, o, I took 18 years, today I'm releasing material with 6. The rest, the rest I with 15 . We invented release with 6 [...] by expertise created. Created as? A thesis of my orientated. We make a proposal, went there, slut gave certain, put, so let's do so. Then we did something that we're revolutionizing" [E1]. To accomplish different ways to develop production, added to knowledge to practice, including with the greatest attempts to 'put into practice' new ways to accomplish the technological development of the plants of sugar cane.

In this sense, transfer technologies is intrinsically related to the exchange of information and knowledge, something that is developed and passed from teacher to teacher within the institution, mainly from the oldest to the youngest. This makes it possible to empower them to the continuity of activities and to develop increasingly expertise with which there is continuity in the future development of technological innovations, and even that projects such as the RIDESA continue. For E1, "we posprema leaving before, preparing to retire čisti pra along with them we do this walk and not wait until the last day [...] only our University has continuity the others don't have anyone to replace the coordinator. The Coordinator will exit and the project will be...".

To ensure that the project exists, in addition to skilled people, it is necessary that there is a continuity in the development of varieties, technological development, whose competition is something that 'pulls the development of innovations': "University is expensive competition, but how is it that we are going to grow [...] the sector, very cleverly, that he begins to say? The variety of Paraná is better, the variety of Viçosa is better. And this is a provocation for us, it was a provocative pras universities, this is great because nobody stopped [...] the next generation we train so also to be extremely competitive" [E1].

Note that the process of technology transfer outlined by the UFPR is, primarily, in the interrelationships that occur and continue to occur through the exchange of expertise, skills and technical knowledge that enables researchers to have increasingly more technical skills for the production of sugarcane plants, including the possibility of transferring knowledge to other institutions, so as to stimulate the process of TT become increasingly fruitful.

\section{DISCUSSION}

Universities develop border scientific knowledge (De Silva \& Rossi, 2018; Etzkowitz, 2017), because they produce numerous knowledge from which innovations emerge (Leydesdorff, 2018). In this scenario, the technology transfer in and by universities is coupled to the nature and type of technology to be transferred, something that occurs considering the fact that the developing academic researches (Huang \& Chen, 2017; Rajalo \& Vadi, 2017) becomes the source of evolution, with the knowledge required to manage the technological changes (Pueyo et al., 2011).

Such transfer of technologies in the development of the cultivation of sugar cane has been something that is fundamental 
to the evolution of activities, mainly because there is a win-win relationship in the exchange of experiences that one party gives the other for the realization of the activities more fruitfully (Easterby-Smith et al., 2008), because the technology is going from one place to another (Carayannis et al., 2015) to be exploited (Petroni et al., 2013). It develops an interaction process through which there is progress in the production of new knowledge (Battistella et al., 2016).

In this case, it was possible to verify the exchange between researchers within the RIDESA netword, as well as the trades and technology transfer among its partners. Fact is, to develop the cultivation of a genetic improvement in the field, it is possible to check the characteristics of climate, soil, etc, elements that are capable of affecting its development. And in interaction with other partners, with the personnel that work in the field, it is possible to check the evolution of the technological innovations.

It is worth mentioning that, for this to occur, it is necessary to exchange of information, resources, technical knowledge and experience (Bozeman, 2000; Bozeman et al., 2015), being the knowledge the main resource (Pagani et al., 2016), as can be noted in the interactions between researchers of the UFPR with other participants of PMGCA. The exchange of information by members of the network, coupled with the technical knowledge and experiences developed in the course of 25 years of research has enabled the expansion of research. However, this only occurs because UFPR develops a trajectory of research, something that affects the TT (Sengupta \& Ray, 2017).

It is noteworthy that the exchange of researchers by universities, along with the possibility of empowerment created by agronomic residency program, are technology transfer tools that enable that the formation of new workers contribute to any future gains.

Also, establishing a trajectory of research, allied to the interrelation with other institutions, opens up the possibility of sharing of risks and benefits (Kaushik et al., 2014; Rogers et al., 2001), as research on a given variety, when wrong, was shared with other members, as well as when it was a successful practice. Thus, time was gained, cost reduced and quality was improved in the evolution of the researches, in addition to improvements in the interrelation between researchers.

With the improvement in the interrelation, with more staff, more communication, information and resources exchange (Kaushik et al., 2014), knowledge from integration of ideas expanded (Bozeman, 2000; Pagani et al., 2016), together with the absorption, distribution, creation of new technologies (Bozeman et al., 2015; Mazurkiewicz \& Poteralska, 2015). Not infrequently, the TT performed increased the production of innovations (Carayannis et al., 2015), because of the large number of genetic innovations of sugar cane developed increasingly in less time, for example, something that went from 18 to 6 years of release of new varieties of sugar cane by UFPR, as highlighted previously.

Even so, are highlighted barriers, since culture is often developed in partnership between the university with other organizations such as the mills of sugar cane highlighted the difficulty in the implementation of procedures and the location of the units (Easterby-Smith et al., 2008). Interconnecting with the productive sector, many times, it is a barrier faced by Brazilian federal public universities, since there is a delay in the formalisation of contracts, the excessive bureaucracy, among other aspects. All of these ultimately affect, albeit indirectly, the processes of TT developed by the UFPR.

\section{FINAL CONSIDERATIONS}

This study arose with the aim of showing the main aspects highlighted in the course of the TT held on the PMGCA developed by means of interorganizational cooperation developed by the UFPR with its partners participants in RIDESA.

It was evidenced, as previously highlighted, that in TT process knowledge is transferred between phases for the production of new technologies, mainly via access to external sources of technology, avoiding the loss of time and resources (Barbieri, 1990). As it developed a genetic improvement program in the institution, UFPR began to conduct research and to train staff increasingly empowered to do so.

Note that there is a constant quest to develop and expand knowledge, so that it is possible to interconnect to the other members of the network and evolve continually. This occurs since transfering technology enables organizations to elevate the production of its innovations (Carayannis et al., 2015), this factor was observed during the research, as the 'big' driver of new plants of sugar cane is in the technology created by a university that partners with UFPR. To analyze what characteristics the plant has, by the researchers' knowledge and skills acquired in years of experience and information exchange, it develops an even better technology (plant), in a shorter space of time, often lowering costs.

Thus, the relationships developed through the network of research developed jointly by ten federal universities, via RIDESA, it became possible to develop the research of sugar cane ever more emphatically, because it created a stimulus to the development of researches with which a university would develop more knowledge about a particular variety of plant, in order to gain greater productivity. And the technology transfer in the course of the process was responsible to enable the development of several new plants and expertise for all members of the project, from which UFPR raises several benefits and tends to continue being benefited by them.

Considering such aspects, some gaps that allow for possible future research could be noticed, such as the possibility of analysis of possible partners and prospects facing the transfer of knowledge and technology in the course of the processes of interaction. And it is also possible to verify how the other universities network participants understand their processes of TT and how they deal with its partners, something that would open up the possibility of a multicase study regarding these prerogatives.

Like any academic study, limitations triggered in the course of research can be seen, for example, regarding the temporal order and quantity of researchers, since the survey was conducted in the course of a year of survey data, but with access to few researchers. The restriction of access to researchers occurred because the other two participating teachers in the coordination of activities at UFPR were not willing to participate in the research, as judged sufficient the aspects listed by the researchers interviewed.

Yet, it is understood that the research itself contributes to the theme of the area, as it raises central aspects of the process of TT by universities, as the one in question in the study. To develop prerogatives focused on the interrelationship, dissemination and expansion of knowledge, the processes 
through which this knowledge is shared is essential to ensure that there is a continuous development of improvements.

\section{ACKNOWLEDGEMENTS}

This study was financed in part by the Coordenação de Aperfeiçoamento de Pessoal de Nível Superior - Brasil (CAPES)

- Finance Code 001.

\section{REFERENCES}

1. Barbieri, J. C. (1990). Produção e Transferência de Tecnologia. São Paulo: Editora Ática.

2. Battistella, C., Toni, A. F. De, \& Pillon, R. (2016). Interorganisational technology/knowledge transfer: a framework from critical literature review. The Journal of Technology Transfer, 41(5), 1195-1234. Retrieved from https://link.springer.com/article/10.1007/s10961-0159418-7

3. Bauer, M. W., \& Gaskell, G. (2002). Pesquisa qualitativa com texto, imagem e som: um manual prático. Petrópolis: Vozes.

4. Bozeman, B. (2000). Technology transfer and public policy: a review of research and theory. Research Policy, 29(4-5), 627-655. Retrieved from https://www.sciencedirect.com/science/article/pii/S004873 3399000931

5. Bozeman, B., Rimes, H., \& Youtie, J. (2015). The evolving state-of-the-art in technology transfer research: Revisiting the contingent effectiveness model. Reserarch Policy, 44(1), 34-49.

6. Caldera, A., \& Debande, O. (2010). Performance of Spanish universities in technology transfer: An empirical analysis. Research Policy, 39(9), 1160-1173. http://doi.org/10.1016/j.respol.2010.05.016

7. Carayannis, E. G., Samara, E. T., \& Bakouros, Y. L. (2015). Innovation and Entrepreneurship: Theory, Policy and Practice. Cham: Springer.

8. Cecere, G., Corrocher, N., Gossart, C., \& Ozman, M. (2014). Technological pervasiveness and variety of innovators in Green ICT: A patent-based analysis. Research Policy, 43(10), 1827-1839. http://doi.org/10.1016/j.respol.2014.06.004

9. Collis, J., \& Hussey, R. (2005). Pesquisa em administração (2nd ed.). Porto Alegre: Bookman.

10. Daros, E., Zambon, J. L. C., \& Oliveira, R. A. (2016). Programa de Melhoramento Genético da Cana-de-Açúcar da UFPR: 25 anos de pesquisa. (E. Daros, J. L. C. Zambon, $\&$ R. A. de Oliveira, Eds.) (1 $\left.{ }^{\mathrm{a}}\right)$. Curitiba: Editora Graciosa.

11. De-Carli, E., Segatto, A. P., \& Alves, F. S. (2016). Capacidades Relacionais na Cooperação Interorganizacional: uma Proposição Teórica. In Anais do XXIX Simpósio de Gestão da Inovação Tecnológica (pp. 18). São Paulo: Anpad. Retrieved from http://www.anpad.org.br/ anpad/eventos.php?cod_evento =5\&cod_evento_edicao=85\&cod_edicao_subsecao=1319

12. De Silva, M., \& Rossi, F. (2018). The effect of firms' relational capabilities on knowledge acquisition and cocreation with universities. Technological Forecasting and Social Change, 133, 72-84. Retrieved from https://doi.org/10.1016/j.techfore.2018.03.004

13. Easterby-Smith, M., Lyles, M. A., \& Tsang, E. W. K. (2008). Inter-Organizational Knowledge Transfer: Current Themes and Future Prospects. Journal of Management Studies, 45(4), 0022-2380. Retrieved from https://www.researchgate.net/publication/4993107_Inter-
Organizational_Knowledge_Transfer_Current_Themes_an d_Future_Prospects

14. Elmuti, D., Abebe, M., \& Nicolosi, M. (2005). An overview of strategic alliances between universities and corporations. Journal of Workplace Learning, 17(1), 115-129. Retrieved from

http://www.emeraldinsight.com/doi/abs/10.1108/13665620 510574504

15. Etzkowitz, H. (2017). Innovation Lodestar: The entrepreneurial university in a stellar knowledge firmament. Technological Forecasting and Social Change, 123, 122$129 . \quad$ Retrieved from https://doi.org/10.1016/j.techfore.2016.04.026

16. Henderson, R., Jaffe, A. B., \& Trajtenberg, M. (1998). Universities as a source of commercial technology: a detailed analysis os university patenting - 1965-1988. The Review of Economics and Statistcs, 80(1), 119-127. Retrieved from http://www.jstor.org/stable/2646734

17. Huang, M.-H., \& Chen, D.-Z. (2017). How can academic innovation performance in university-industry collaboration be improved? Technological Forecasting and Social Change, 123, 210-215. http://doi.org/10.1016/j.techfore.2016.03.024

18. Kaushik, A., Kumar, S., Luthra, S., \& Haleem, A. (2014). Technology transfer: Enablers and barriers - A review. International Journal of Technology Policy and Management, 14(2), 133-159. Retrieved from https://www.researchgate.net/publication/261297216_Tec hnology_transfer_Enablers_and_barriers_-_A_review

19. Leydesdorff, L. (2018). Synergy in Knowledge-Based Innovation Systems at National and Regional Levels: The Triple-Helix Model and the Fourth Industrial Revolution. Journal of Open Innovation: Technology, Market and Complexity, 4(2), $16 . \quad$ Retrieved from https://doi.org/10.3390/joitmc4020016

20. Lundvall, B.-A. (2007). National Innovation SystemsAnalytical Concept and Development Tool. Industry \& Innovation, 14(1), 95-119. http://doi.org/10.1080/13662710601130863

21. Mazurkiewicz, A., \& Poteralska, B. (2015). Barriers to technology transfer at R\&D organisations. In R. P. Dameri \& L. Beltrametti (Eds.), 10th European Conference on Innovation and Entrepreneurship. Reading: Academic Conferences and Publishing International Limited. Retrieved from https://www.researchgate.net/publication/290911719_Barr iers_to_technology_transfer_at_RD_organisations

22. Merriam, S. B. (2009). Qualitative Research: a guide to design and implementation. San Francisco: Jossey-Bass.

23. Noveli, M., \& Segatto, A. P. (2012). Processo de Cooperação Universidade-Empresa para a Inovação Tecnológica em um Parque Tecnológico: Evidências Empíricas e Proposição de um Modelo Conceitual. Revista de Administração e Inovação - RAI, 9(1), 81-105. Retrieved from http://www.revistas.usp.br/rai/article/viewFile/79251/pdf_ 65

24. Pagani, R. N., Zammar, G., Kovaleski, J. L., \& Resende, L. M. (2016). Technology transfer models: typology and a generic model. International Journal of Technology Transfer and Commercialisation, 14(1), 2016. Retrieved from

https://www.inderscienceonline.com/doi/pdf/10.1504/IJTT C.2016.079923 
25. Petroni, G., Verbano, C., Bigliardi, B., \& Galati, F. (2013). Strategies and determinants for successful space technology transfer. Space Policy, 29(4), 251-257. Retrieved from https://www.sciencedirect.com/science/article/abs/pii/S026 596461300060X

26. Pueyo, A., Garcia, R. G., Mendiluce, M., \& Morales, D. (2011). The role of technology transfer for the development of a local wind component industry in Chile. Energy Policy, 39(7), 4274-4283. Retrieved from https://www.researchgate.net/publication/227415720_The _role_of_technology_transfer_for_the_development_of_a _local_wind_component_industry_in_Chile

27. Rajalo, S., \& Vadi, M. (2017). University-industry innovation collaboration: Reconceptualization. Technovation, 62-63(December 2015), 42-54. http://doi.org/10.1016/j.technovation.2017.04.003
28. Ridesa, R. I. para o D. do S. S. (2018). Universidades Federais Ridesa. Retrieved September 30, 2017, from https://www.ridesa.com.br/universidades

29. Rogers, E. M., Rogers, E. M., Takegami, S., Takegami, S., Yin, J., \& Yin, J. (2001). Lessons learned about technology transfer. Technovation, 21, 253-261.

30. Sengupta, A., \& Ray, A. S. (2017). University research and knowledge transfer: A dynamic view of ambidexterity in british universities. Research Policy, 46(5), 881-897. http://doi.org/10.1016/j.respol.2017.03.008

31. UFRRJ. (2018). Programa de Residência em Agronomia. Retrieved January 13, 2019, from http://www.residenciaemagronomiaufrrj.com.br/editais/edi tal-07-2018/

32. Yin, R. K. (2015). Estudo de Caso: Planejamentos e Métodos $\left(5^{\mathrm{a}}\right)$. Porto Alegre: Bookman.

33. Yin, R. K. (2016). Pesquisa Qualitativa: do início ao fim. Porto Alegre: Penso. 